\section{Remittances and corruption in Nigeria}

Remittances and corruption in Nigeria

Folorunsho M. Ajide

Department of Economics, University of Ilorin, Ilorin, Nigeria, and John A. Olayiwola

Department of Management and Accounting, Obafemi Awolowo University, Ile-Ife, Nigeria

\begin{abstract}
Purpose - In this paper, we investigate the impact of remittances on control of corruption in Nigeria for a period of 1986-2016.

Design/methodology/approach - The study uses ARDL modeling framework, dynamic OLS estimation, variance decomposition and impulse response analysis to examine the relationship between the two variables. Findings - The study finds that remittances significantly improve the control of corruption in Nigeria. We further examine the robustness test of the results using dynamic OLS estimation, variance decomposition and impulse response analysis. Our results remain significant and consistent to the earlier one reported in ARDL framework which supports the extant literature.

Practical implications - Our study suggests that international remittances can be used, through the crossborder transfer of norms and practices, to significantly impact the socioeconomic progresses of a country by reducing corruption.

Originality/value - The existing studies on the relationship between corruption and remittances document conflicting results. In addition, study on corruption - remittances nexus that specifically focuses on any African country is largely absent despite the fact that most of the countries in the region are recognized as highly corrupt. This paper provides insights on how remittances can be used as part of tool kits to control corruption in African nation.
\end{abstract}

Keywords Control of corruption, Remittances, Bound test, Nigeria

Paper type Research paper

\section{Introduction}

Corruption has been identified as one of the major challenges in Nigeria. The country has been consistently ranked as one of the major corrupt countries in the world and particularly in African region (Abu and Staniewski, 2019). The Transparency International (2019) ranks the country 146 out of 180 countries, with a score of 26 out 100 . This score is also below the global average of 43 and 32 for African region. In West Africa, Nigeria is ranked higher than Guinea Bissau with a score of 18 . In addition, it has been established that corrupt behavior is not only rampant in Nigeria but also the economies and citizens in African regions in general are the worst hit by the corruption (Abu and Staniewski, 2019; Igiebor, 2019). Notwithstanding the reiteration by the government on commitment to fight corruption, the score indicates that the situation is getting worse year by year. This situation needs urgent actions beyond conventional system of fighting corruption.

There are two opposing empirical evidences on the role played by remittances in a corrupt environment. The first group states that remittances increase the level of corruption. This

\section{JEL Classification - D73, F24}

(C) Folorunsho M. Ajide and John A. Olayiwola. Published in Journal of Economics and Development. Published by Emerald Publishing Limited. This article is published under the Creative Commons Attribution (CC BY 4.0) license. Anyone may reproduce, distribute, translate and create derivative works of this article (for both commercial and non-commercial purposes), subject to full attribution to the original publication and authors. The full terms of this license may be seen at http://creativecommons. org/licences/by/4.0/legalcode
Received 26 April 2020 Revised 3 July 2020 Accepted 4 August 2020 
JED

23,1

group emphasizes that remittances permit governments to divert spending away from public-goods provision but toward private goods mainly because the migrant intends to penetrate into the political system by providing funds for the provision of public goods and services. The citizens feel relax because they now have alternatives that can provide public goods even without mounting pressure on the government (Ahmed, 2012; Tyburski, 2014). Remittances enable and serve as a form of social insurance that allows recipients to replace public spending with their private money (Berdiev et al., 2013; Majeed, 2016). This means that it is possible to have positive relationship between corruption and remittances. Furthermore, the second group of studies shows that remittances can serve as part of toolkits for tackling corruption. This implies that remittances can reduce the level of corruption in a country, simply because it serves as one of the incentives for the migrants and the remittances recipients to control corruption. Studies show that the migrants are the people that affect national policy and drag the government to deliver on their mandate through their wealth of experiences gained by working abroad. They remit purposively to improve living standards of their people, making connections and provide opportunities to become politically active in their home countries. This acts as a good voice to compel government to reduce waste and govern efficiently (Tyburski, 2014; Tusalem, 2018; Borja, 2020).

The arguments above show that there is no consensus among the scholars to date on the relationship between remittances and corruption. In this study, we investigate the impact of remittances on control of corruption in Nigeria. We advance the extant literature in a number of ways. (1) Unlike other studies, our study is one of the few studies conducted using an African country, Nigeria. This country is ranked as one of the most corrupt countries in the world (Transparency International, 2019). The rationale behind the use of a single country is because corruption has to do with specific tradition, values, norms and institutions peculiar to a society. As norms and social culture are varied among countries, the laws to be enforced in each country would be different. The nature and pattern of corruption in different countries is not universal, and assumption of universality with regard to corruption could be misleading as taking by some panel regression studies (Berdiev et al., 2013; Majeed, 2016). (2) Remittances to Nigeria have continued to increase over the years. According to World Bank (2018), Nigeria is the largest remittance recipients in sub-Saharan Africa with about $\$ 22 b n$ in 2017, followed by Senegal $(\$ 2.2 b n)$, Ghana $(\$ 2.2 b n)$, Kenya $(\$ 2.0 b n)$, Uganda $(\$ 1.4 b n)$ and Mali $(\$ 1.0 b n)$. It has been predicted that these countries would still be the largest remittances in the region. Despite inflow of these funds into the country, no study has investigated its impact on control of corruption in Nigeria and sub-Saharan Africa in general.

Therefore, using Nigeria as a study ground for testing the relationship between corruption and remittances is very important because of the opposing views in the empirical literature which needs further investigations. (3) Taking remittance inflows as part of policy toolkit to control corruption would never be a bad idea in Nigeria as few studies have suggested that most migrants may have stronger preferences against corruption and they remit mainly to improve living standards of their home. This may actually make them to have interest in the corruption control by acting as economic agents in enforcing policy against the corrupt government in their home country. This is usually done to again political power in the long run especially when their presence is being felt in their home countries (Conway and Cohen, 1998). (4) On methodological contribution, our study is the first to examine the impact of remittances inflow on control of corruption in a time series framework. Specifically, we use ARDL modeling technique to gain a further insight into the relationship, and we proceed to examine how control of corruption would response to shock on remittances variables in Nigeria. In a nutshell, the highlighted approaches make our study to be unique, and we examine the relationship in both short-run and long-run. On overall, our results suggest that remittances can form part of the policy toolkits for fighting against corruption. The next 
section reviews the literature. In Section 3, we discuss the methodology of the paper. In Section 4, we discuss the results, while Section 5 concludes the paper.

\section{Review of literature}

\subsection{Corruption in Nigeria}

Corruption is the abuse of public office, privileges, authorities and powers for private and selfish gains (Egger and Hannes, 2005). Notwithstanding the anti-corruption measures put in place by the Nigerian government, the country has dropped from 144 in 2018 to 146 in 2019 out of 180 countries behind Botswana (34) and Mauritius (56) in Africa (Transparency International, 2019). The pattern of corruption in Nigeria takes the form of diversion of state assets and resources by the elites and political class for private gains and personal consumptions. They also hold control over national wealth and always desire to retain political power which is the surest way of carrying out their corrupt practices. Furthermore, the discovery of oil and natural gas and the rise of public administration are among the notable causes of high rate of corruption in Nigeria. $80 \%$ of revenue from oil that accrue to Nigerian state, it is only $1 \%$ of the population that benefits from the revenue. It is important to also note that high level of corruption still persists in the country because public officials are using official power to corruptly amass wealth for their private gains. The tactics commonly employ include the following: poor public spending on education and healthcare and inflation of construction prices which lead to higher rate of unemployment and poverty level. In general, this practice has led to poor standards of living in the country (Abu and Staniewski, 2019). However, the government have been making efforts to reduce the corruption rate, but greed, ostentatious lifestyle, customs, tribalism and the attitude of citizens still make the practice to persistently increase in the country (Akindola, 2017).

\subsection{Theoretical issues}

Theoretically, it has been well documented that institutional environments matter in strengthening and enhancing the remittance impact in the economy, particularly in developing countries (Kadozi, 2019; Borja, 2020). Remittances can contribute to human development generally, but corruption and weak institution can reduce its effectiveness (Ajide, 2019). There are studies that show that remittances may improve the level of corruption. This is because the recipients may not be encouraged to use the foreign funds in a useful manner (such as assets acquisition) due to the cumbersome and corrupt process to legalize property. There are two conflicting views on remittance corruption nexus, thus: the substitution perspective emphasizes that remittances permit governments to divert spending away from public goods provision and toward private goods and patronage (Ahmed, 2012; Tyburski, 2014). In other words, remittance inflows can encourage individuals to purchase public goods and services instead of relying on government for its provision (Abdih et al., 2012). With remittances in place, government can free ride and misappropriate or appropriate public funds for its own use because the citizens have felt relaxed. This supports the argument of Barajas et al. (2009). This view reveals that remittance inflows demotivates individual households to evaluate the governments' policy performance and creates a moral hazard problem in which the cost of poor governance performance is partially shifted to the remittance sender (Majeed, 2016).

Furthermore, the accountability perspective reveals that there are incentives for migrants and their beneficiaries to use remittance inflows as a political instrument to control corruption (Tyburski, 2012). Migrants are key people that can affect national policy and drag the government to deliver on their mandate. Migrants control corruption because they remit purposively to improve living standards in the home countries by transmitting their
Remittances and corruption in Nigeria

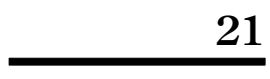


JED

23,1

22

experiences in living abroad to families and friends (Levitt, 1998). This makes them to connect with their people and provide opportunities to become politically active back home which acts as a good voice to compel government to reduce waste and deliver effectively (Tyburski, 2014). Remittances may reduce the risk of income losses by serving as another source of household income, most especially when the family income is hurt by recession, more remittance would be requested from family members working abroad (Borja, 2020).

\subsection{Empirical literature}

Few studies have attempted to provide empirical insights on how corruption correlates with remittances. However, their submissions remain debatable. Considering the important implications that international remittances might have on every economic settings, the empirical literature investigating the interaction between government behavior as regards to corruption and remittances is scanty. In a natural experimental design, Ahmed (2013) demonstrates that remittances deteriorate the quality of governance, especially in countries with weak democratic institutions. It reduces the level of government delivery in terms of public services, e.g. health care and school enrollment. Berdiev et al. (2013) examine the effect of remittances on corruption in 111 counties. They document that remittances encourage corruption, most importantly in nonOECD countries. Ricciardulli (2019) investigates how government reacts on remittance inflows using IV estimation techniques. The results show that remittance significantly influences government spending practices. This submission is consistent with the study of Majeed (2016) who reports that remittance promotes corruption in high corrupt economies in a sample of 122 countries. Tusalem (2018) uses data provided by the Philippine National Statistics Office and the National Statistical Coordinating Board of the Philippines to prove empirically that the number of migrants (by province) and the amount of remittances sent by migrants are positively associated with governmental effectiveness. Furthermore, Borja (2020) empirically confirms that remittances significantly affect human development and reduce corruption. Considering the huge inflow of migrant remittance into Nigerian economy, our study investigates the impact of remittances on control of corruption in Nigeria.

\section{Data and methodology}

\subsection{Model specification and analytical strategies}

The main objective of this study is to examine the impact of remittance inflow on control of corruption in Nigeria. In line with this, we infer the theoretical foundation of this study from the conventional discussion that higher income has the tendency to empower individuals politically and improve the quality of institution (Przeworski et al., 2000; Treisman, 2000; 2007). Scholars also recognize that financial transfers like remittances can directly generate rent-seeking behavior and may as well encourage corruption (Friedman, 1958; Alesina and Beatrice, 2002). This means that remittances may enable individual households to purchase public goods, while having access to such goods may encourage citizens to have little or no incentives to hold government accountable to provision of public goods and services and thereby freeride and misappropriate funds for personal use (Abdih et al., 2012). According to Ricciardulli (2019) citing Tyburski (2014) "just as increased income better protects households from economic shocks, remittances offer citizens the ability to protect themselves from clientelistic relationships, in which politicians dole out private goods in favor of political support. When citizens are better able to support their own consumption, they depend less on private goods supplied by politicians. By breaking the clientelistic cycle that would otherwise maintain the authority of corrupt governments, political competition is encouraged" (P. 7). This supports the theoretical assertion that the presence of remittances may have beneficial impacts on governance by empowering households to pressurize 
government through a bottom-up approach. This implies that remittances enable citizens to pressure the political leaders for better governance. Following this line of thought, we modify the empirical model of Berdiev et al. (2013) and Majeed (2016) and present our empirical model as:

$$
\text { Corr }=f(\mathrm{REM}, \mathrm{KO}, \mathrm{UN}, \mathrm{TAX})
$$

Furthermore, it is important to note that a reverse causality may exist between remittances and corruption (Ahmed, 2013; Majeed, 2016).This means that endogeneity bias need to be considered in our estimations. Apart from the fact that remittance may impact corruption control, it is possible for a country with higher level of corruption control to attract higher remittance. Measurement error may as well occur due to the flow of remittance in shadow economy. In order to control for these problems, this study employs autoregressive distributed lag (ARDL) modeling approach because (1) it is frequently used especially when the number of period involved is relatively short. In our case, we utilize data from 1986 to 2016. (2) This approach is applicable irrespective of level of stationary provided it is not more than I(1). (3) It also takes care of endogeneity and measurement errors.

To apply this, we conduct bound test approach to cointegration which uses F-statistic to confirm the long run equilibrium among variables. As our sample is relatively small in which the number of years is 31 , we used the critical values as reported by Narayan and Narayan (2004). The study generates critical values with one set referring to upper bound, I(1) series and the other for the lower bound critical value, $\mathrm{I}(0)$ series. If the variables are cointegrated, the $F$ test statistic must exceed their respective upper critical values. This would make us proceed to estimate the error correction model which reveals the speed of adjustment to longrun equilibrium level after shock.

From Equation (1), we specify our model to follow ARDL framework as in Equation (2):

$$
\begin{aligned}
\Delta \operatorname{Cor}_{t}= & \propto_{0}+\sum_{i=1}^{k} \prod_{i} \Delta \operatorname{Cor}_{t-i}+\sum_{i=0}^{k} \gamma_{i} \Delta \operatorname{REM}_{\mathrm{t}-\mathrm{i}}+\sum_{\mathrm{i}=0}^{\mathrm{k}} \theta_{\mathrm{i}} \Delta \mathrm{KO}_{t-i}+\sum_{i=0}^{k} \psi_{i} \Delta \mathrm{UN}_{t-i} \\
& +\sum_{i=0}^{k} \delta_{i} \Delta \mathrm{TAX}_{t-i}+\alpha_{1} \operatorname{Cor}_{t-1}+\alpha_{2} \mathrm{REM}_{t-1}+\alpha_{3} \mathrm{KO}_{t-1}+\alpha_{4} \mathrm{UN}_{t-1} \\
& +\alpha_{5} \mathrm{TAX}_{t-1}+\epsilon_{t}
\end{aligned}
$$

Where dependent variable (Cor) is corruption control while the key independent variable is REM which stands for remittance inflow. The control variables include $\mathrm{KO}$ which is the degree of financial openness, UN is unemployment rate, while TAX is tax revenue. $\Delta$ is firstdifference operator and $k$ is the optimal lag length while $\varepsilon_{t}$ is the white noise. For robustness check, we reestimate our baseline model using dynamic OLS. We add institutional variables including law and order (LAW) to capture the effectiveness of government enforcements on corruption. In addition, we examine the sensitivity of the key variables by introducing the military in politics (MIP) in our estimation. This variable captures the impact of military participation in politics and the higher level of political risk on corruption.

Our choice of control variables are drawn from extant literature, institutional variables like law and order, military in politics tend to affect corruption level. The quality of laws may reduce the presence of corruption, while the military in government weakens corruption control (Ahmed, 2013; Majeed, 2016). Law and order serve as deterrent to corruption and rest on the ability of the rule of law in a nation. We also consider tax revenue as a control variable. Imam and Jacobs (2014) show that corruption correlates with tax revenue. Their results hint that tax revenue collection decreases as corruption increases in a nation (also see, Dissou and Yakautsava, 2012). Furthermore, our study includes unemployment rate in the model to capture the level of economic 
JED

23,1

condition. The recent study of Adjor and Kebalo (2018) show that unemployment correlates with the level of corruption. Unemployment rate reflects the level of economic condition of a country, therefore, if the rate is too high, it may increase the level of corruption in a country (Perugini and Signorelli, 2010; Rendahl, 2016). We add financial openness to follow the extant literature that documents that financial liberalization is associated with control of corruption in developing countries (Ghate, 2018). This is because economic integration policies give freedom to international movement of funds including illegal; money to international safe havens. Demirguc-Kunt and Detragiache (1998) illustrate that financial openness gives financial institutions more freedom which increase the operational risk. However, the higher opportunity of risk might lead to more fragility which depends on different levels of institutional environment.

\subsection{Measurement of variables and sources of data}

\section{(1) Dependent variable}

Control of corruption (Cor) is the corruption perception index provided by International Country Risk Guide (ICRG). It has been used by many studies (Majeed, 2016; Cooray and Schneider, 2018). The ICRG index scored 0 as totally corrupt and maximum of 6 as not corrupt. This means that the indices are better interpreted as higher values on the corruption indices denote better control of corruption (Cooray and Schneider, 2018).

\section{(2) Independent and control variables}

The key independent variable is remittances (REM) which is measured as the workers' remittances and compensation of employees received (\% of GDP). Data on remittances are sourced from World Bank Development Indicators. Control variables include financial openness (KO). It measured the capital account restriction or the degree of financial openness. We source the data from Chinn and Ito (2006). unemployment (UN) is proxied as unemployment as a percentage of total labor force. The data are sourced from World Bank Development Indicators. Tax revenue (TAX) is tax revenue as a percentage of GDP. These data are sourced from Central Bank of Nigeria and Federal Inland Revenue Services. Law and order (LAW) is an index in which high value means strong political institutions and sound court system. This index is used to capture the effectiveness of government enforcements on corruption which ranged from $0-6$. Furthermore, the data on military in politics (MIP), law and order (LAW) are sourced from International Country Risk Guide (ICRG), while the index of MIP is scaled from 0-6 meaning that higher risk ratings (6) indicate a greater degree of military participation in politics and a higher level of political risk.

\section{Results and discussion}

\subsection{Preliminary test}

In time series econometrics, it is important to know the nature of data so as to ensure that appropriate techniques are applied. Having this in mind, we start by conducting unit root test for the purpose of determining the stationarity level of the variables. Table 1 and 3 present the unit root test and cointegration test results of our variables after determining the lag length as reported in Table 2.

Table 1 shows that all our variables are stationary at first differencing after using augmented Dicky-Fuller (ADF) test, Philips-Peron (PP) test and Kwiatkowski-PhillipsSchmidt-Shin (KPSS). It is important to note that in KPSS, the presence of a unit root is not in the null but in the alternative hypothesis. The test argues that the absence of a unit root is not a necessary proof for the data to be stationary but, by design, may be trend-stationary (Lipsey and Sjöholm, 2011; Sarker and Khan, 2020). As reported in Table 1, the results show that all our variables are stationary at first differencing, and we proceed to determine the lag length for our models. 


\begin{tabular}{|c|c|c|c|c|}
\hline Variables & $\mathrm{ADF}$ & PP & KPSS & Order \\
\hline Cor & $-4.5993 * * *(0.0010)$ & $-4.5420 * * *(0.0012)$ & $0.118574^{1}$ & $\mathrm{I}(1)$ \\
\hline REM & $-5.810684 * * * *(0.0000)$ & $-5.936264 * * *(0.0000)$ & $0.170465^{1}$ & $\mathrm{I}(1)$ \\
\hline $\mathrm{KO}$ & $-4.87625 * * *(0.0005)$ & $-4.867900 * * *(0.0005)$ & $0.164640^{1}$ & I(1) \\
\hline UN & $-5.130509 * * * *(0.0003)$ & $-5.12468 * * *(0.0003)$ & $0.146372^{1}$ & $\mathrm{I}(1)$ \\
\hline Tax & $-5.600466 * * *(0.0001)$ & $-5.596009 * * *(0.0001)$ & $0.146409^{1}$ & $\mathrm{I}(1)$ \\
\hline Law & $-3.321^{* *}(0.0241)$ & $-3.25292 * *(0.0269)$ & $0.11657^{1}$ & $\mathrm{I}(1)$ \\
\hline MIP & $-3.388123 * *(0.0198)$ & $-3.385935 * * *(0.0199)$ & $0.539082^{1}$ & I(1) \\
\hline
\end{tabular}
in () are $P$-values. In addition, ${ }^{1}$ means significance at $1 \%$ level for KPSS, and KPSS 's asymptotic critical values are 0.73900 for $1 \%, 0.46300$ for $5 \%$ and 0.34700 for $10 \%$ level

\section{Remittances and corruption in Nigeria

1)

1)

$(1)$

(1)

(1)

Table 1. Unit root test

\begin{tabular}{|c|c|c|c|c|c|c|}
\hline Lag & $\log \mathrm{L}$ & LR & FPE & AIC & $\mathrm{SC}$ & HQ \\
\hline \multicolumn{7}{|c|}{ Endogenous variables: COR REM KO UN TAX } \\
\hline 1 & -190.6702 & NA & 6.097028 & 15.97557 & $17.17542^{*}$ & 16.33235 \\
\hline 2 & -163.6881 & 33.97744 & 6.197736 & 15.82875 & 18.22845 & 16.54231 \\
\hline 3 & -137.7104 & 23.09135 & 9.729832 & 15.75632 & 19.35587 & 16.82666 \\
\hline 4 & -78.25993 & 30.82615 & $3.092049 *$ & $13.20444^{*}$ & 18.00384 & $14.63155^{*}$ \\
\hline
\end{tabular}

Source(s): Authors'* indicates lag order selected by the criterion

LR: sequential modified LR test statistic (each test at $5 \%$ level)

FPE: Final prediction error

AIC: Akaike information criterion

Table 2.

SC: Schwarz information criterion

VAR lag order

HQ: Hannan-Quinn information criterion

selection criteria

Cor $=f\left(\right.$ REM, KO, UN, Tax), $F$-Statistics $=15.23438^{* * *}$

Cor $=f($ REM, KO, UN, MIP), $F$-Statistics $=8.245620 * *$

Cor $=f\left(\right.$ REM, KO, UN, Law), $F$-Statistics $=5.04185^{* *}$

Cor $=f($ REM, KO, UN, Tax, MIP), F-Statistics $=5.6454 * *$

Note(s): **donates significant at $5 \%$

Source(s): Authors' Computation
$K=4, \operatorname{ARDL}(4,1,4,4,4)$

$K=4, \operatorname{ARDL}(4,3,4,2,4)$

$K=4, \operatorname{ARDL}(4,4,4,2,4)$

$K=5$, ARDL $(2,2,2,2,0,1)$

ARDL Bound Test

(Null Hypothesis: No Long-Run Relationship

In Table 2, we determine the lag length for our baseline model. We take decision using the results of AIC which states that the suitable length is four. We further test for cointegration among the variables as reported in Table 3. The null hypothesis is that there is no long-run relationship among the variables. However, our results support the alternative hypothesis. This means that long- run equilibrium exists among the variables. We also test for cointegration after inserting military in politics (MIP) and law and order (LAW) in the model. The results still confirm that there is a long-run relationship. In addition, as all our variables are integrated of order one based on the unit test results, we use Johasen and Juselius cointegration test to confirm the bound test cointegration results of our baseline model (see Table 4), in which the procedure is based on likelihood tests. Table 4 presents the results of trace test statistics ( $\lambda$ trace) and the maximum statistics ( $\lambda$ max).

It could be deduced from the cointegration results that the absolute values of trace and maximum statistics tests of the residuals exceed their critical value in the hypothesis at $5 \%$. 
JED 23,1

26

This means that there is at least one cointegrating vector among the variables. We therefore proceed to estimate our baseline model using ARDL modeling approach.

\subsection{Main results}

Tables 5 and 6 report the results of ARDL conducted for short-run and long-run respectively. ECT is the error correction term which is the measure of speed adjustment toward equilibrium after a shock. The anticipated value of the parameter range is -1 to 0 , while 0 means no convergence and -1 means perfect convergence (Sarker and Khan, 2020).

\begin{tabular}{lccccccc}
\hline $\begin{array}{l}\text { Hypothesized no. of } \\
\text { CE(s) }\end{array}$ & Eigenvalue & $\lambda_{\text {trace }}$ & $5 \%$ at CV & Prob.** & $\lambda_{\text {Max }}$ & $5 \%$ CV & Prob.** \\
\hline None* $^{*}$ & 0.901943 & 100.1393 & 69.81889 & 0.0000 & 65.02165 & 33.87687 & 0.0000 \\
At most 1 & 0.415013 & 35.11760 & 47.85613 & 0.4418 & 15.31857 & 27.58434 & 0.7472 \\
At most 2 & 0.332512 & 20.10496 & 29.79707 & 0.4158 & 11.31857 & 21.13162 & 0.6155
\end{tabular}

Table 4.

Johasen and Juselius cointegration test
Source(s): Authors' computation

$*$ denotes rejection of the hypothesis at the 0.05 level

**MacKinnon-Haug-Michelis (1999) $p$-values
Table 5.

Short-run regression (ARDL), dependent variable: cor

\begin{tabular}{|c|c|c|c|c|}
\hline Variable & Coefficient & Standard error & $t$-Statistic & Probability \\
\hline $\mathrm{D}(\mathrm{COR}(-1))$ & -0.172579 & 0.217764 & -0.792504 & 0.4640 \\
\hline $\mathrm{D}(\mathrm{COR}(-2))$ & -0.353411 & 0.189282 & -1.867112 & 0.1209 \\
\hline $\mathrm{D}(\mathrm{COR}(-3))$ & $-0.430162^{* *}$ & 0.167257 & -2.571865 & 0.0499 \\
\hline $\mathrm{D}(\mathrm{REM})$ & $0.019078 * * *$ & 0.004634 & 4.117161 & 0.0092 \\
\hline $\mathrm{D}(\mathrm{KO})$ & $-0.315721^{* *}$ & 0.092678 & -3.406635 & 0.0191 \\
\hline $\mathrm{D}(\mathrm{KO}(-1))$ & -0.023966 & 0.044224 & -0.541921 & 0.6111 \\
\hline $\mathrm{D}(\mathrm{KO}(-2))$ & -0.002754 & 0.041282 & -0.066711 & 0.9494 \\
\hline $\mathrm{D}(\mathrm{KO}(-3))$ & $-0.094627^{*}$ & 0.041256 & -2.293657 & 0.0703 \\
\hline $\mathrm{D}(\mathrm{UN})$ & 0.001584 & 0.001717 & 0.922851 & 0.3984 \\
\hline D(UN(-1)) & $-0.027769^{*}$ & 0.005749 & -4.830195 & 0.0048 \\
\hline D(UN(-2)) & $0.026058^{*}$ & 0.005864 & 4.444138 & 0.0067 \\
\hline D(UN(-3)) & $-0.033314^{*}$ & 0.007498 & -4.442827 & 0.0067 \\
\hline $\mathrm{D}(\mathrm{TAX})$ & 0.002819 & 0.001416 & 1.990415 & 0.1032 \\
\hline $\mathrm{D}(\mathrm{TAX}(-1))$ & -0.003020 & 0.002074 & -1.456155 & 0.2051 \\
\hline $\mathrm{D}(\mathrm{TAX}(-2))$ & -0.002332 & 0.001824 & -1.278569 & 0.2572 \\
\hline $\mathrm{D}(\mathrm{TAX}(-3))$ & $-0.006788^{* * *}$ & 0.001634 & -4.153106 & 0.0089 \\
\hline $\operatorname{ECT}(-1)$ & -0.665291 *** & 0.159901 & -4.160651 & 0.0088 \\
\hline
\end{tabular}

Source(s): Authors' Computation *, **, *** Means significance at 10\%, 5\%, 1\%

Table 6. (ARDL), dependent variable: cor

\begin{tabular}{lccrc}
\hline Variable & Coefficient & Std. Error & $t$-Statistic & Prob. \\
\hline REM & $0.043610^{* *}$ & 0.011841 & 3.682979 & 0.0142 \\
KO & $-0.996420^{* *}$ & 0.208727 & -4.773804 & 0.0050 \\
UN & $0.050192^{*}$ & 0.020991 & 2.391074 & 0.0623 \\
TAX & 0.013414 & 0.007634 & 1.757185 & 0.1392 \\
C & -0.589777 & 0.710920 & -0.829597 & 0.4446
\end{tabular}

Source(s): Authors' Computation *, **, *** Means significance at 10\%, 5\%, 1\% 
The ECT coefficient is negative and significant at $1 \%$ level. This supports our bound test results in Table 3. It means there is long- run adjustment among the variables which is approximately $66.5 \%$. The remittance (REM) is positive and significant in relation to the control of corruption variable. Specifically, in the long run the remittance improves the control of corruption in Nigeria. We document the same result for short run which is consistent with the submission of Tusalem (2018). He empirically proves that remittances improve the effectiveness of governance in Philippines and that remittances induce the governments to spend more on citizens' well-being through provision of public goods and services.

The logic behind this submission is that most migrants have the capacity to hold on with their remittances especially when they envisage that the state is blighted with corruption and inefficiencies. According to Tusalem (2018), "this is attributed to the fact that migrants usually identify with their host country's political culture where host state governments are characterized by the efficient delivery of public goods and services and higher levels of political accountability. As a result, migrants can be construed as social agents of change as they use their earning capacity to influence the growth of national economies and influence public goods provision" (P. 2). Tyburski (2014) states that remittance inflows are associated with better control of corruption especially in a more democratic states. This opposes the submission of Majeed (2016). In a panel of 122 countries, he reports in the midst of least corrupt countries, that remittances do not appear to increase corruption, while it does in most corrupt countries. Our results do not support this because Nigeria is rated high among the corrupt countries in the world, and the present result shows that remittances can be used to control corruption in the country. This assertion is consistent with the empirical work of Ivlevs and King (2017) who document after using data from the Gallup Balkan Monitor survey and instrumental variable analysis, that having relatives abroad reduces the likelihood of bribing public officials. This renders bribe-taking behavior by public officials less acceptable and reduces the likelihood of being asked for bribes by public officials. However, Nikolova and Marinov (2017) report that financial windfalls increase the tendency of local government to engage in corrupt practices.

Furthermore, the coefficient of unemployment rate is positive and significant in the long run but negative in the short run. This implies unemployment improves control of corruption in the long run, while opposite is the case in the short run. This is in agreement with the view of Lim (2017). He states that corrupt economy reduces the physical and human capital investment quality which in turns increases the unemployment rate. In some cases, it increases the level of uncertainties in the economy. In addition, the coefficient of financial openness is negative and significant. This implies that financial openness discourages the efforts to control corruption in Nigeria. This result supports the empirical work of Izibili and Aiya (2007). They find that financial deregulation increases the level of corruption in Nigeria. The study of Gong and Zhou (2014) in China establishes that liberalization increases corruption level. Openness may also generate new opportunities for corruption. According to Tanzi (1998), paying bribes gives advantage of winning foreign contracts and as well opens opportunities to access markets in order to enjoy some incentives, e.g. tax holidays. Bribes optimize the mutual interests of politicians and firms. Politicians want to stay in office by reelection and to do this, they need finance for their campaigns, while firms need business incentives. Therefore, greater openness could lead to a higher incidence of corruption (Majeed, 2014).

On the diagnostic indicators, Table 7 shows that our model is free from heteroskedasticity problems, and the Jarque-Bera results also confirm the normality of the model. The adjusted $R$-square gives the explanatory power of the model and shows goodness of fit leaving out $2 \%$ unexplained variations. The $F$-statistic (137.70) shows the overall significance of the model. By examining the report in Table 7, our model passes these tests. Figure 1 presents the CUSUM and CUSUM of square for the estimation. It can be seen that the coefficients are stable.

Remittances and corruption in Nigeria 


\subsection{Robustness check}

We perform further analyses to examine the robustness check on our variable of interest. We reestimate our model using dynamic least squares (DOLS). DOLS constructs an efficient estimator that eliminates asymptotically the feedback effect in the cointegrating regression. It augments the cointegrating regression with lags and leads, so that the resulting cointegrating equation error term is orthogonal to the entire history of the stochastic regressor innovations. Table 8 presents the regression results of DOLS. The results support the results of ARDL.

Table 7.

Diagnostic test

Heteroskedasticity test: Breusch-Pagan-Godfrey

Breusch-Godfrey serial correlation LM Test

Normality test (Jarque Bera)

$F$-statistic

Adjusted $R$-squared

Source(s): Authors' Computation
$21.48015(0.430)$

$4.134320(0.137)$

$0.922184(0.6305)$

$137.7091(0.000016)$

0.991025

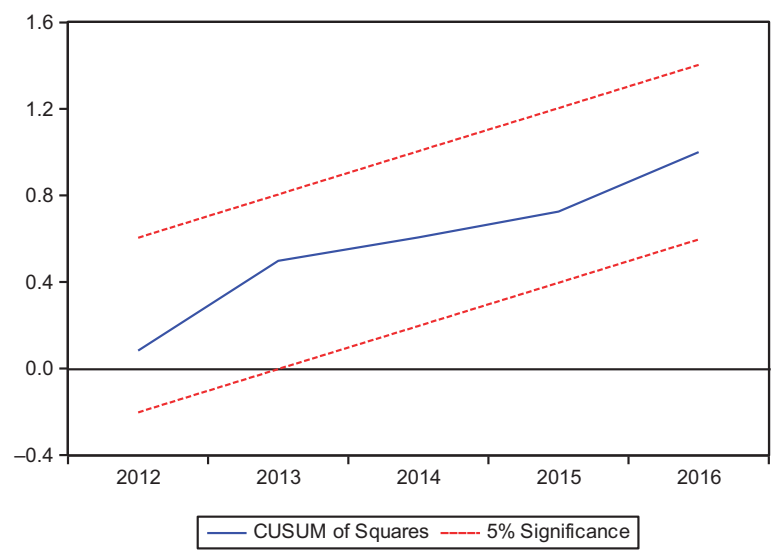

Figure 1.

CUSUMand CUSUM of square for model for ARDL model

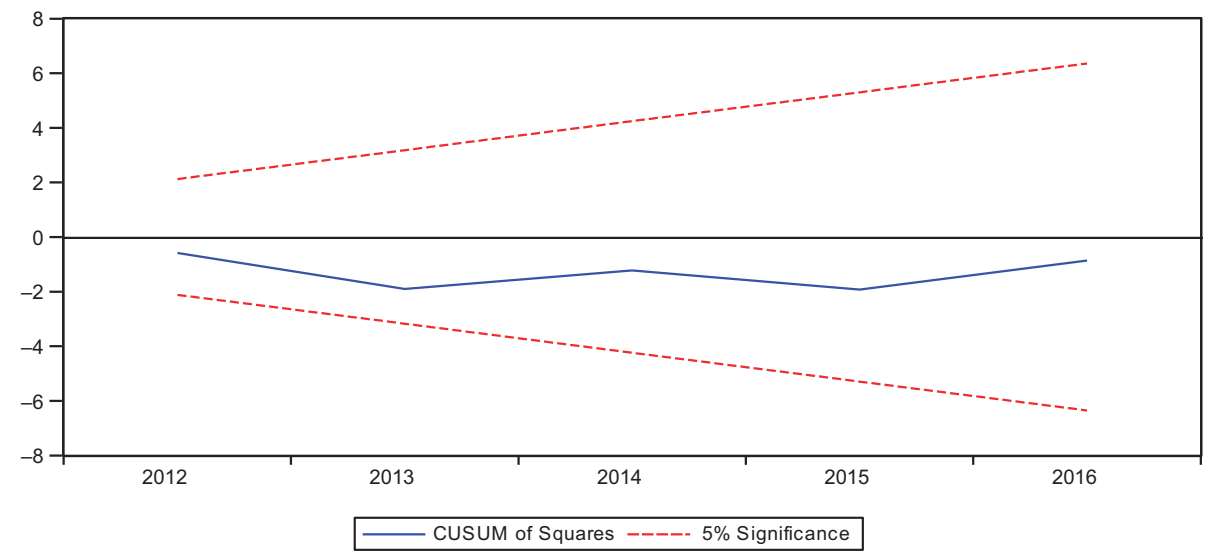

Source(s): Authors Computation 
It shows that the coefficient of remittances (REM) has positive and significant impact on control of corruption (Cor) in Nigeria. Furthermore, we introduce two other causes of corruption such as military in politics (MIP) and law and order (LAW) into the estimations to follow Majeed and Macdonald (2010). Their coefficients reduce the control of corruption. The coefficient of remittances still remains robustly significant with positive sign and coefficient fluctuate between 0.014 and 0.05 .

\subsection{Variance decomposition and impulse response}

The study takes a further step to estimate variance decomposition and impulse response of our variables of interest to identify duration of adjustment of the variables if the key variables are shocked. In this sense, the relative exogeneity or endogeneity depends on the proportion of the variance explained by its own past. Impulse response functions can be used to understand the interactions among our studied variables. It shows the reaction of variables to shocks within the system. Figure 2 shows that when a shock to remittances (REM) makes the corruption of corruption (COR) to move through the graph negatively and moving toward equilibrium but never near the position of equilibrium. Furthermore, Table 9 reports the variance decomposition showing how much a shock to one variable impacts the (variance of the) forecast error of a different one. In our case, over $70 \%$ of the variance in the forecast error of control of corruption (CRP) is explained by a shock to

\begin{tabular}{lccc}
\hline Variables & DOLS & DOLS & \multicolumn{1}{c}{ DOLS } \\
\hline REM & $0.057830^{*}(0.0791)$ & $0.014942^{* *}(0.0299)$ & $0.017605^{* * *}(0.0002)$ \\
KO & $-1.419972^{* *}(0.0167)$ & $0.177780(0.2762)$ & $0.025183(0.7642)$ \\
UN & $0.035791(0.1146)$ & $0.026985^{* * *}(0.0090)$ & $0.013561^{* * *}(0.0002)$ \\
LAW & $-0.503418^{* *}(0.0587)$ & & \\
Tax & & $0.006138(0.1008)$ & \\
MIP & & $-0.589286^{*}(0.0011)$ & $-0.416918^{* * *}(0.0000)$ \\
$C$ & $0.526791(0.3670)$ & $2.047706^{*}(0.0000)$ & $1.959839^{* * *}(0.0000)$ \\
$R$-squared & 0.879375 & 0.985196 & 0.982396 \\
Adjusted $R$-squared & 0.703922 & 0.942900 & 0.956789 \\
S.E. of regression & 0.165272 & 0.072580 & 0.063138
\end{tabular}

Remittances and corruption in Nigeria 


\begin{tabular}{llllllll} 
JED & \multicolumn{1}{c}{ S.E. } & COR & REM & KO & UN & TAX \\
\cline { 2 - 7 } Period & S & 0.139976 & 100.0000 & 0.000000 & 0.000000 & 0.000000 & 0.0000000 \\
& 1 & 0.202924 & 90.69432 & 0.286140 & 6.570999 & 1.862875 & 0.585663 \\
& 2 & 0.226999 & 83.55855 & 3.149215 & 7.727966 & 1.503789 & 4.060483 \\
& 3 & 0.244572 & 74.91307 & 6.637756 & 6.894751 & 2.521072 & 9.033351 \\
& 4 & 0.261832 & 66.40441 & 8.683118 & 6.019495 & 4.170859 & 14.72211 \\
$\mathbf{3 0}$ & 5 & 0.279253 & 58.63436 & 9.411920 & 5.292152 & 5.831788 & 20.82978 \\
& 6 & 0.297725 & 51.58557 & 9.400511 & 4.655939 & 7.343689 & 27.01429 \\
& 7 & 0.317213 & 45.53747 & 9.004372 & 4.103748 & 8.544071 & 32.81034 \\
Table 9. & 8 & 0.337249 & 40.56531 & 8.455408 & 3.635357 & 9.349029 & 37.99490 \\
Variance & 9 & 0.357410 & 36.55675 & 7.893473 & 3.241169 & 9.798560 & 42.51005
\end{tabular}

decomposition of COR Source(s): Authors: Computation, Cholesky Ordering: COR, REM, KO, UN, TAX

itself followed by larger proportion explained by remittances (REM) and financial openness (KO).

\subsection{Further discussion of results}

Corruption can be categorized in different ways, but the most common among them are administrative corruption and political corruption among others. It may include both financial and nonfinancial considerations given to public sector officials who use the public office for private benefits. It is the abuse of public power for private benefits (World Bank, 1997). Most of the commonly mentioned causes of corruption include existence of monopoly rents in which its distribution is under the control of authorities where discretionary power and operations are not transparent (Rose-Ackerman, 1997). Tax laws complexity and procedures, lack of adequate supervision and monitoring, lack of the commitment of political leadership and overall environment in government sector are another common sources of corruption. Meanwhile, due to its obstacle to poverty alleviation especially in Africa, many have called for its eradication in our daily economic activities.

The existing literature show that governance reforms, improvement in institutional capacity development, restructuring in every aspects of economic sectors, property rights, privatization, regulations, access to transparent information and pricing reforms serve as the common anticorruption practices in developing countries. Furthermore, monitoring and designing of specialized databases and formulation of risk assessment tools may as well serve as part of tool kits for controlling corruption (Talvitie, 2017). Notwithstanding the rich literature on anticorruption agenda, our study also presents an insight that remittance can serve as parts of anticorruption toolkits in Nigeria. Our findings show that good governance, strengthening institutional quality and free movement of remittances inflow can serve the government in its fight against corruption. The findings of Tavares (2003) also demonstrate that international official flows reduce the level of corruption which suggests that remittances, among others, can control corruption in developing countries and improve the level of governance. Our results support the view that government regulations in international flows through financial and other institutions to improve the efficiency in allocations of resources can control the level of corruption. This submission is consistent with the study of Tyburski (2014) who analyses that international remittance inflows do influence corruption control. Remittance inflow is associated with better control of corruption especially in a democratic setting. Migrant remittances can be used to boost household income, improve the standard of living and increase households' investment in education which alternates credit scarcity while households gain more access to public goods and services (Adida and Desha, 2011). Remittances may as well encourage households' recipients to place pressure on leaders for better governance (Tyburski, 2014). Based on this line of 
argument, our findings showcase its ways in the theoretical puzzle by supporting accountability approach on the relationship between remittance and corruption which explains that migrant groups may take advantage of remittances to coerce public office holders for better control of corruption.

\section{Conclusion and policy implication}

In this paper, we examine the impact of remittances on control of corruption in Nigeria for a period of 1986-2016. Within the ARDL modeling framework, we establish that remittances significantly improve the control of corruption in Nigeria. We further examine the robustness test of the results using dynamic OLS estimation. Our results remain significant and consistent to the earlier one reported in ARDL framework which supports the extant literature. In a single country study, we reaffirm that remittance inflows are associated with better control of corruption. The policy implication is that international remittances can be used, through the cross-border transfer of norms and practices, to significantly impact the socioeconomic progresses of a country by reducing corruption. It follows that effective communication and effective means of international remittances can help in controlling corruption in Nigeria. This can be done through the transfer of normative intangibles including economic policies that could be considered by policy makers in both destination and origin countries. It may also serve as an incentive for diasporas to interact with home communities so as to encourage inflow of international remittances in the country. In addition, migrant remittances can induce the process of reducing bribe payment and official corruption generally. This is because it makes the governments to perform which serves as a way to prove their legitimacy. It can constrain the incumbent government in a particular administration from relying on patronage through distribution of gifts during elections' campaigns as the households are financially empowered through international remittances.

\section{References}

Abdih, Y., Chami, R., Dagher, J. and Montiel, P. (2012), "Remittances and institutions: are remittances a curse?", World Development, Vol. 40 No. 4, pp. 657-666.

Abu, N. and Staniewski, N.W. (2019), "Determinants of corruption in Nigeria: evidence from various estimation techniques”, Economic Research- Ekonomska Istraživanja, Vol. 32 No. 1, pp. 3058-3082, doi: 10.1080/1331677X.2019.1655467.

Adjor, D. and Kebalo, L. (2018), "Does corruption matter for unemployment in SADC countries?", Review of Economic and Business Studies, Vol. 11 No. 2, pp. 65-92, doi: 10.1515/rebs-2018-0074.

Adida, C. and Desha, G. (2011), "Do migrants improve their hometowns? remittances and access to public services in Mexico 2000-2005", Comparative Political Studies, Vol. 44 No. 1, pp. 3-27.

Ahmed, F. (2012), "The Perils of unearned foreign income: aid, remittances, and government survival", American Political Science Review, Vol. 106 No. 1, pp. 146-65.

Ahmed, F.Z. (2013), "Remittances deteriorate governance", Review of Economics and Statistics, Vol. 95, pp. 1166-1182.

Ajide, F.M. (2019), "Remittances, bank concentration and credit availability in Nigeria”, Journal of Development Policy and Practice, Vol. 4 No. 1, doi: 10.1177\%2F2455133318811727.

Akindola, R. (2017), "Military incursion, tribalism and poor governance: the consequences for development in Nigeria”, Mediterranean Journal of Social Sciences, Vol. 8 No. 5, pp. 151-155, doi: 10.1515/mjss-2017-0033.

Alesina, A. and Beatrice, W. (2002), "Do corrupt governments receive less foreign aid?", American Economic Review, Vol. 92, pp. 1126-1137.

Barajas, A., Chami, R., Fullenkamp, C., Gapen, M. and Montiel, P. (2009), "Do workers' remittances promote economic growth?", IMF Working Papers, available at: SSRN: http://ssrn.com/ abstract51442255.
Remittances and corruption in Nigeria 
JED

23,1

32

Berdiev, A.N., Kim, Y. and Chang, C. (2013), "Remittances and corruption”, Economics Letters, Vol. 118, pp. 182-185.

Borja, K. (2020), "Remittances, corruption, and human development in Latin America", Studies in Comparative International Development, doi: 10.1007/s12116-020-09299-1.

Conway, D. and Cohen, J. (1998), "Consequences of migration and remittances for Mexican transnational communities", Economic Geography, Vol. 74 No. 1, pp. 26-44.

Cooray, A. and Schneider, F. (2018), "Does corruption throw sand into or grease the wheels of financial sector development?”, Public Choice, Vol. 177, pp. 111-133, doi: 10.1007/s11127-018-0592-7.

Demirg-Kunt, A. and Detragiache, E. (1998), Financial Liberalization and Financial Fragility, World Bank website, available at: http://siteresources.worldbank.org/DEC/Resources/847971251813753820/6415739-1251813951236/demirguc.pdf (accessed 16 December 2019).

Dissou, Y. and Yakautsava, T. (2012), "Corruption, growth, and taxation”, Theoretical Economics Letters, Vol. 2, pp. 62-66, doi: 10.4236/tel.2012.21011.

Egger, P. and Winner, H. (2005), "Evidence on corruption as an incentive for foreign direct investment”, European Journal of Political Economy, Vol. 21 No. 4, pp. 932-952.

Friedman, M. (1958), "Foreign economic aid: means and objectives", Yale Review, Vol. 47, pp. 500-516.

Ghate, P.S. (2018), "Does financial liberalization increase corruption? evidence from a panel analysis", Senior Projects Spring 2018, Vol. 274, available at: https:/digitalcommons.bard.edu/senproj_ s2018/274.

Gong, T. and Zhou, N. (2014), "Corruption and marketization: formal and informal rules in Chinese public procurement", Regulation \& Governance, doi: 10.1111/rego.12054.

Igiebor, G.O. (2019), "Political corruption in Nigeria: implications for economic development in the fourth republic", Journal of Developing Societies, Vol. 35 No. 4, pp. 493-513.

Imam, P.A. and Jacobs, D. (2014), "Effect of corruption on tax revenues in the Middle East", Review of Middle East Economics and Finance, Vol. 10, pp. 1-24.

Ivlevs, A. and King, R.M. (2017), "Does emigration reduce corruption?", Public Choice, Vol. 171, pp. 389-408, doi: 10.1007/s11127-017-0442-z.

Izibili, M. and Aiya, F. (2007), "Deregulation and corruption in nigeria: an ethical response", Journal of Social Sciences, Vol. 14 No. 3, pp. 229-234.

Kadozi, E. (2019), "Remittance inflows and economic growth in Rwanda", Research in Globalization, doi: 10.1016/j.resglo.2019.100005.

Levitt, P. (1998), "Social remittances: migration driven local level forms of cultural diffusion", International Migration Review, Vol. 32 No. 4, pp. 926-948.

Lim, K.Y. (2017), "The dynamics of corruption and unemployment in a growth model with heterogeneous", Working papers 198144263, Lancaster University Management School, Economics Department.

Lipsey, R.E. and Sjöholm, F. (2011), "Foreign direct investment and growth in East Asia: lessons for Indonesia”, Bull Indones Econ Stud, Vol. 47 No. 1, pp. 35-63, doi: 10.1080/00074918.2011.556055.

Majeed, M.T. (2014), "Corruption and trade", Journal of Economic Integration, Vol. 29 No. 4, pp. 759-782, doi: 10.11130/jei.2014.29.4.759.

Majeed, M.T. (2016), "Migrant remittances and corruption: an empirical analysis”, Pakistan Journal of Applied Economics, Vol. 26 No. 1, pp. 15-41.

Majeed, M.T. and Macdonald, R. (2010), Corruption and the Military in Politics: Theory and Evidence from Around the WorldWorking Paper, University of Glasgow, 2010-34.

Narayan, S. and Narayan, P.K. (2004), "Determinants of demand for Fiji's exports: an empirical investigation”, The Developing Economies, Vol. 42 No. 1, pp. 95-112, doi:10.1111/j.1746-1049. 2004.tb01017.x. 
Nikolova, E. and Marinov, N. (2017), "Do public fund windfalls increase corruption? evidence from a natural disaster", Comparative Political Studies, Vol. 50 No. 11, pp. 1455-1488.

Perugini, C. and Signorelli, M. (2010), "Youth labour market performance in European regions", Economic Change and Restructuring, Vol. 43 No. 2, pp. 151-185.

Przeworski, A., Michael, E.A., Jose, A.C. and Fernando, L. (2000), Democracy and Development: Political Institutions and Well-Being in the World, 1950-1990, Cambridge University Press, Cambridge.

Rendahl, P. (2016), "Fiscal policy in an unemployment crisis", Review of Economic Studies, Vol. 83 No. 3, pp. 1189-1224.

Ricciardulli, J. (2019), "Do remittances encourage poor governance practices?”, The UGA Journal of Economics, Vol. 1 No. 2, pp. 1-25.

Rose-Ackerman, S. (1997), Corruption and development Paper Presented in Ninth. Annual Bank Conference in Development, World Bank, WA, DC.

Sarker, B. and Khan, F. (2020), "Nexus between foreign direct investment and economic growth in Bangladesh: an augmented autoregressive distributed lag bounds testing approach", Financial Innovation, Vol. 6 No. 10, doi: 10.1186/s40854-019-0164-y.

Talvitie, A. (2017), "Observed differences in corruption between Asia and Africa: the industrial organization of corruption and its cure", Transportation Research Procedia, Vol. 25, pp. 4472-4490.

Tanzi, V. (1998), “Corruption around the world: causes, consequences, scope, and cures”, IMF Working Paper No. 98/63, available at SSRN: https://ssrn.com/abstract=882334.

Tavares, J. (2003), “Does foreign aid corrupt?”, Economics Letters, Vol. 70, pp. 99-106.

Transparency International (2019), "Corruption perception index", available at: https://www. transparency.org/.

Treisman, (2000), "The causes of corruption: a cross-national study", Journal of Public Economics, Vol. 76, pp. 399-457.

Treisman, (2007), "What have we learned about the causes of corruption from ten years of crossnational empirical research?”, Annu. Rev. Polit. Sci., Vol. 10, pp. 211-44.

Tusalem, R.F. (2018), "Do migrant remittances improve the quality of government? Evidence from the Philippines", Asian Journal of Comparative Politics, pp. 1-31.

Tyburski, M.D. (2012), "The resource curse reversed? remittances and corruption in Mexico", International Studies Quarterly, Vol. 56 No. 2, pp. 339-350, doi: 10.1111/j.1468-2478.2012.00721.x.

Tyburski, M.D. (2014), "Curse or cure? migrant remittances and corruption”, The Journal of Politics, Vol. 76 No. 3, pp. 814-824, doi: 10.1017/S0022381614000279.

World Bank (1997), World Development Report: The State in a Changing World, World Bank, WA, DC.

World Bank (2018), Migration and Remittances: Recent Development Outlook. Migration and Development Brief 29, World Bank, WA, DC.

\section{Further reading}

Gyimah-Brempong, K. and de Camacho, S.M. (2006), "Corruption, growth, and income distribution: are there regional differences?”, Economics of Governance, Vol. 7 No. 3, pp. 245-269, doi: 10.1007/ s10101-005-0008-2.

\section{Corresponding author}

Folorunsho M. Ajide can be contacted at: ajide2010@gmail.com

For instructions on how to order reprints of this article, please visit our website:

www.emeraldgrouppublishing.com/licensing/reprints.htm

Or contact us for further details: permissions@emeraldinsight.com

Remittances and corruption in Nigeria

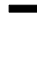

